\title{
CARTELS BY ROBOTS - CURRENT ANTITRUST LAW IN SEARCH OF AN ANSWER
}

\author{
Václav Šmejkal ${ }^{*}$
}

\begin{abstract}
The discussion about influence of PC algorithms on the theory and practice of competition (anti-cartel) law has its practical justification. PC algorithms enable the processing of such a volume of data, plus a very quick and lasting, non-emotional reaction, that the underlying assumptions on which competition protection has so far been built cease to work. Transparency of markets ceases to foster competition and the market can be riddled of price competition without any hint of contact or agreement that is currently considered as a cartel. The possibility of suppressing price competition in online trading markets cannot but provoke a reaction of the current competition law. The paper thus attempts to analyze this issue through a review of the ongoing debate. It provides information on where the current and future threats to competition are seen today and what recipes to tackle them are presented. It looks in a critical manner at the instruments that the current competition law can use for this purpose. It focuses exclusively on the question of pricing made by computer algorithms, which may or may not fulfil the present definition of a cartel. The issue of abuse of a dominant position is paid attention only when it is relevant to deal with price collusion on oligopolistic markets.
\end{abstract}

KEYWORDS: robot, algorithm, conscious parallelism, cartel, competition law

\footnotetext{
Associate Professor at Charles University in Prague School of Law and ŠKODA AUTO University in Mladá Boleslav; smejkalv@prf.cuni.cz.
} 


\section{INTRODUCTION ${ }^{1}$}

According to experts working on artificial intelligence (AI) implications, the AI machines will be able to replace us with $50 \%$ probability „,only“ in 2040 $2045 .^{2}$ It is however today's reality that robots, or more precisely the computer algorithms, are able to trade very efficiently instead of people, even at prices that are substantially higher than the competitive ones. The following text attempts to analyze precisely this issue of competition protection through the results of the current discussion on algorithms and anti-competitive collusion. This debate is fuelled by responses to the seminal book of Ariel Ezrachi and Maurice E. Stucke Virtual Competition: The Promise and Perils of the Algorithm-Driven Economy, published in November $2016^{3}$, as well by the OECD's Round Table Algorithms and Collusion that took place in June 2017. ${ }^{4}$ The aim here is to provide information on where the current and future threats to competition are perceived and what recipes to cope with them are being proposed. The following lines try to throw a critical look at the tools that the current competition law can use for this purpose. The focus is made exclusively on the question of pricing made by computer algorithms, which may or may not fulfil the current definition of a cartel (given in Article 101 of the Treaty of the Functioning of EU and Section 1 of the US Sherman Act). The issue of abuse of dominant position is reflected only to the extent that it coincides with the issue of parallel pricing as it is above all the price collusion committed by online trading robots that represents the field where today's reality combines with an already predictable, albeit still "fantastic" future.

\footnotetext{
1 This text has been elaborated within the project of the student scientific research "Finance and information technology as drivers of legal regulation in the European Union countries and their criminal law aspects" which is realized in the years 2017 - 2019 at the Faculty of Law of the Charles University, SVV 260 360/2017.

2 Umělá inteligence tiká jako bomba (AI is like a ticking bomb), interview of P. Houda with s N. Bostrom, Lidové noviny - Česká pozice 25. 6. 2017. <https://www.pressreader.com/ czech-republic/lidove-noviny/20170624/281513636157560 >, last accessed on 12/12/2017.

3 Harvard University Press 2016.

4 See the OECD documents available through the website $<$ http://www.oecd.org/competition/algorithms-and-collusion.htm_>, and especially OECD (2017), Algorithms and Collusion: Competition Policy in the Digital Age < www.oecd.org/competition/algorithms-collusion-competition-policy-in-the-digital-age.htm >, last accessed on 12/12/2017.
} 


\section{DENIAL OF OLD TRUTHS}

If we stem from the widest definition of the algorithm as ,a sequence of rules that should be performed in an exact order to carry out a certain task ${ }^{\text {"5 }}$, there is nothing that comes to the world specifically with powerful PCs and AI. The new challenge lies in the fact that computer algorithms can work with a huge amount of data, unimaginably quickly, without interruptions, without emotions, and increasingly also without human involvement. Their grasp of certain market parameters (obtainable from the Internet), their ability to evaluate and run a follow-up action are exaltedly referred to as "divine," emphasizing the inaccessibility of similar awareness, speed, endurance and coldness for human beings. To illustrate the shift, it suffices to remind that thanks to the PC algorithm, the well-known Internet business trader Amazon performed in November 2012 as many as 2.5 million changes in charged prices within one day, while the classic Wall-Mart retail chain changed at the same time around 50,000 prices per month. ${ }^{6}$

The volumes and availability of processed information, the speed of response, the flawlessness, and the persistence of the PC algorithms all stand out from the experience of the world in which the antitrust was formed. There is thus a new challenge to its doctrinal assumptions, to the definition of major anti-competitive offenses, to standards of their detection and proving. The full and instant knowledge, as well as a steady rational response capability, have always belonged among the key prerequisites for a perfect competition mod$e l$. However, the empirical experience with transparency provided by online tools shows the opposite: perfect information for market participants does not necessarily lead to greater but, on the contrary, to a less intense price competition. Such effect has been witnessed by the authorities in Chile, Australia and Germany when they tried to display and update online the information about current fuel prices at petrol stations in the country. The well-intentioned effort to release motorists from the grip of overcharging local micro-monopolies by informing them about an alternative price available at acceptable distance ended up with an overall (albeit non-nationwide) increase in the price level by $10 \%$ on average. ${ }^{7}$

5 OECD Directorate General for Financial and Enterprise Affairs Competition Committee. Algorithms and Collusion - Background Note by the Secretariat DAF/COMP(2017)4, June 9, 2017, p. 6.

6 Mehra, S., K., Antitrust and the Robo-Seller: Competition in the Time of Algorithms, Minnesota Law Review Vol. 100, 2016 p. 1345.

7 OECD Directorate General for Financial and Enterprise Affairs Competition Committee. Algorithmic Collusion: Problems and Counter-Measures - Note by Ezrachi, A. and Stucke, M. E. DAF/COMP/WD(2017)25, May 31, 2017, p. 7-8. 
The rivalry based on a competitive uncertainty has been underpinned in theory by the well-known model of prisoner's dilemma. ${ }^{8}$ Doubts about whether one can rely on an opponent with whom it is not possible to communicate directly have dictated to "every prisoner" to prefer an aggressive strategy that disregarded the opponent's interests and fought him ruthlessly. Such a strategy, applied to prices, usually led to the downward movement of prices or occasionally event to price wars that were beneficial for consumers. But as soon as smart machines are capable to monitor online each change in price and follow it quickly and precisely before the price war initiator were able to profit from it, the competition through the lowering of prices is quickly assessed as ineffective. On the other hand, the upward price movement, also shared by a "flash speed", appears to be a great strategy for any vendor's algorithm programmed to ensure profitability. And because PCs do not have human imperfections and weaknesses, they can pursue this profitable strategy without hesitation. This truth is evidenced by an almost anecdotal incident with the cost of an expert book on genetics that has climbed to US $\$ 23$ million per copy in online sales. The online seller A programmed his algorithm to keep the price a few percent above the seller B's price, while the seller B ordered his algorithm not to lose more than a slight percentage on the price of the seller $\mathrm{A}$. The upper price limit was not set and so the price of A steadily tried to overtake the price of B, which, on the contrary, did not hesitate to catch up with A...9

With price-generating algorithms, something similar can occur in every market in which IT can be fully exploited in pricing ${ }^{10}$ even though it does not need to be a narrowly oligopolistic market to which the classical antitrust usually imputed the ability to converge prices or (in the dictum of EU competition law) to facilitate the abuse of collective dominance. With the trading via PC algorithms, it is assumed that such a price parallelism is sustainable for 5 and 6 undertakings without the

\footnotetext{
8 „Two accomplices locked in separate cells. Each is offered three choices by the police: (1) if both confess to the charges, both will be jailed for five years, (2) if only one confesses, he will be freed but the non-confessor will be jailed for ten years, or (3) if neither confesses, both will be tried for a minor offense and will be jailed for one year." Read more: < http://www. businessdictionary.com/definition/prisoner-s-dilemma.html >, last accessed on 12/12/2017.

9 The case was referred to by the EC Commissioner for competition, Margrethe Vestager in her speech: Algorithms and competition pronounced at the Bundeskartellamt 18th Conference on Competition. Berlin March 16, 2017. For detailed information, including the pictures of the sellers' webs and their price curves see Thomas, A., Algorithmic price-fixing may be the new frontier of antitrust. Fideres.com, March 18, 2016.

10 For instance, two-thirds of retailers in developped economies currently use algoritms to track prices of their competitors and some of them also use the software to autonomously adjust their prices. See in Macaulay, T., Could algorithmic pricing be good for consumers? Techworld, July, 10 2017. <http://www.techworld.com/data/could-algorithmic-pricing-make-collusion -invisible-3661103>, last acceessed on 12/12/2017.
} 
need for mutual contacts let alone agreements. ${ }^{11}$ In addition, every successful internet business must strive to maximize his own network effect. Only when his offer becomes the first or the second click choice for a large number of internet users he would keep its web shop alive and profitable in a market where it is not difficult to enter, but where it is very difficult - because of the network effect - to acquire a large enough market share and persist. Major online platforms therefore tend to create a rather narrow oligopoly, whose instability, caused by the dynamics of the Internet environment and the technological innovation can be offset by an easily accessible collusion. The fact that this collusion in online markets is easier to achieve is also confirmed by the OECD study: because of the fact that online trading is characterized by market transparency and frequency of interactions, i.e. by factors that make collusion significantly easier. ${ }^{12}$

The ease of online price collusions goes hand in hand with the difficulty of their detection. The fact that customers usually learn about an overcharge (supposing that they do not analyze themselves the business model and thus could not discover the vendor's algorithm) only when it amounts to a blatant price aberration, makes the life difficult also for competition authorities. Under the circumstances of the rapidly changing price levels, which in the markets with predominantly online trading (securities, software, music ...) do not have a clear and palpable benchmark, a gradual but inconsistent upward trend in prices may be difficult to detect and prove. ${ }^{13}$ And when it is captured and eventually proved, decisions and sanctions are often important only for not allowing the offender to escape without punishment. As a rule, they come so late that the market is already far from looking for the news about what was distorted six or eight years ago. An example of the problem is the decision (of the experienced and usually efficient) US Securities and Exchange Commission, which in October 2016 penalized a high-frequency stock trader for manipulating stock exchange rates on Wall Street during 2009.14

11 OECD Directorate General for Financial and Enterprise Affairs Competition Committee. Algorithmic Collusion: Problems and Counter-Measures - Note by Ezrachi, A. and Stucke, M. E. DAF/COMP/WD(2017)25, May 31, 2017, p. 6.

12 Mordall, J. OECD Workshop Adresses Algorithms and Collusion Issues: Kluwer Competition Law Blog. July 17, 2017 <http://competitionlawblog.kluwercompetitionlaw.com/2017/07/17/ oecd-workshop-addresses-algorithms-collusion-issues/>, last accessed on 12/12/2017.

13 Price collusion may be difficult to detect just for the fact that it does not need to take form of a unified and long maintained price. On the contrary in an algorithm-driven market a ,price snake" is perfectly imaginable that would twist around a slightly but inconsistently rising axis. This would resemble a perfect adaptation to market's ups and downs and it would be very difficult to tell if the price at a specific moment were really above its competitive level.

14 Deshayes, M., Les algorithmes, ont-ils pris le pouvoir? Sciences Humaines: Les grandes enjeux du monde contemporain. Mars-Avril 2017, p. 155. 


\section{MANY CHANCES, MANY RISKS}

Naturally, the online merchants that use pricing algorithms do not deserve just shame. It has already been said that online markets represent a transparent, dynamic environment in which it is easier to enter than into markets dominated by the brick and mortar retail chains. This bring the opportunity of meeting between such offers and demands that would have never met without the Internet, which gives a chance to new competition, to greater choice and easier consumer satisfaction. For large online business players, however, it is no longer possible to separate this type of trading from smart software that monitors the price fluctuations, the supply and the demand, the group and the individual customer preferences, as well as many other factors that can be important for success in trading. Thus, on the one hand, the environment of the digital economy promises more competition for the benefit of consumers and, on the other hand, gives the companies in the online markets the tools to turn the pro-competitive characteristics of the environment into their opposite by an easy elimination of price competition to the detriment of consumers. The question is whether competition authorities can quickly and correctly disclose the misuse of pricing algorithms, whether the current competition law has at its disposal enough of efficient tools to protect the positives and offset the negatives of online markets in the digital economy.

To illustrate what has been just said, there is no need to go far. The network of shared individual transport, the world-famous Uber, brought revolutionizing competition into the world of taxi services, giving the opportunity to improve personal budgets to thousands of car owners and gaining fidelity of millions of users in large cities around the world. As a proper disruptive technology, it posed a challenge to several sectors of traditional business regulation, from tax collection, though employee rights to antitrust. Founder of Uber, T. Kalanick, has created an algorithm evaluating immediate supply and demand for transport, and then changing every five minutes the billed price (depending on a specific city zone and possibly other undisclosed factors ${ }^{15}$ ). Uber's algorithm then determines the price charged by individual drivers belonging to the network whose members know that a certain percentage of the price set by the network is guaranteed to them.

15 Leber, J. The Secrets of Uber's Mysterious Seurge Pricing Algorithm Revelaed, Fast Company Daily Newsletter, October 29, 2015. < https://www.fastcompany.com/3052703/the-secrets-of-ubers-mysterious-surge-pricing-algorithm-revealed $>$, last accessed on 12/12/2017. 
In the Meyer $v$. Kalanick litigation ${ }^{16}$, the founder of Uber defended himself by asserting that prices set by the algorithm simply followed "natural market fluctuations". The fact however was that these fluctuations were not perceived and evaluated by imperfect human senses and brains but by a refined PC algorithm. ${ }^{17}$ The resulting price thus was not the result of competitive uncertainty but, on the contrary, of the certainty of the drivers driving for Uber that no one else in the network would offer another price to the customer. That is why Judge Rakoff did not meet Kalanick's request to reject Meyer's claim and stated that Kalanick had created a hub-and-spoke conspiracy, including a vertical agreement between the hub (Kalanick-Uber) and spokes (drivers), as well as a horizontal agreement between the drivers that consented to would follow the conditions set by Uber - all that with the outcome consisting in limitation of price competition to the detriment of Uber customers.

\section{TYPOLOGY OF ALGORITHMIC DISTORTION OF COMPETITION}

The history of misuse of pricing algorithms has already its decided cases, however those have been so far only cases in which the PC algorithm was merely a tool in the hands of undertakings concluding a cartel agreement (or acting in concert). In the US, this is the so-called Poster Cartel of D. Topkins and several other sellers of posters (whose identity was not revealed). ${ }^{18}$ They let the PC algorithm carry out their agreement to align the prices of posters offered through Amazon online sale. In the EU, there is the decision of the Court of Justice in the case C-74/14 Eturas. ${ }^{19}$ Eturas created online booking software E-TURAS, which was offered to travel agencies. After certain time, Eturas informed these agencies by e-mail that, in order to "normalize competition", the

16 Case 1:15-cv-09796-JSR Meyer v. Kalanick United States District Court Southern District of New York, Document 37. For more information see Vegari, A. N., Lobue, R. P., District Court Finds Uber CEO, by Driving for Uber, May be Liable for Driving Up Prices. Patterson Belknap Antitrust Update, April 6, 2016. < <https://www.antitrustupdateblog.com/districtcourt-finds-uber-ceo-driving-uber-may-liable-driving-prices/>, last accessed 12/12/2017.

17 Mehra, S. K., Antitrust and the Robo-Seller: Competition in the Time of Algorithms. Minnesota Law Review, Vol. 100, 2016 p. 1324.

18 Department of Justice. Press Release Number: 15-421. Former E-Commerce Executive Charged with Price Fixing in the Antitrust Division's First Online Marketplace Prosecution. April 6, 2015. <https://www.justice.gov/opa/pr/former-e-commerce-executive-charged-price-fixing-antitrust-divisions-first-online-marketplace $>$, last accessed on 12/12/2017.

19 Case C-74/14 "Eturas" UAB and others v. Lietuvos Respublikos konkurencijos taryba. Judgment of the Court of Justice, January 21, 2016. ECLI:EU:C:2016:42. 
online shared software would limit the maximum level of discounts offered by travel agencies to $3 \%$. In essence, this was the analogy of the hub-and-spoke "Uber model": Eturas set the margin of discounts and thus restricted the price competition between travel agencies to the detriment of their clients. In the proceedings before the Court, it was not that much the substantive law question whether the competitive pricing had been distorted, but rather the issue of how exactly it had to be proved (the fact of acquaintance with the message) in order to establish which travel agencies participated in the cartel which had to be clarified.

Authors such as Ezrachi and Stucke, or the OECD study ${ }^{20}$, divide these already known cases, which do not require any changes to the current EU or US competition law, into two separate types. Poster cartels can be referred to as the messenger scenario or alternatively as a misuse of the monitoring algorithm. The price-generating algorithm is deliberately misused there by cartelists as a means to effectively implement and monitor their collusion. The question for the competition authorities may be how to detect the violation, but not its legal qualification, as the agreement between undertakings preceded the use of the algorithm in clear violation of Art 101 TFEU or Sec 1 of Sherman Act.

The second relatively simple type of collusion is the hub-and-spoke scenario, also described as a misuse of the parallel algorithm. Such an algorithm, often created by a third party who does not directly participate in the competition on the relevant market, but usually plays the role of sales coordinator for a larger number of independent sellers. They either agree to such a coordination, or tacitly accept it, i.e. they are supposed know that their behavior is being concerted. Disclosure and proof of anticompetitive offense can be a little more complicated here because different vertical and horizontal "concertations" are combined, and participants may be to a different degree aware of being part of a price cartel. Even in this type of cases, however, the algorithm is not more than a technical means facilitating an agreement between companies. The current antitrust therefore knows how to cope with it.

To the two following scenarios of distortion of competition the same "simplicity" does not apply, and according to Ezrachi and Stucke, OECD and other authors, the competition law faces because of them the real new challenges. The former of the two is referred to as the predictable agent scenario or as a misuse of the signalling algorithm. In this type of cases, each undertaking has an independently selected algorithm that continually monitors and adjusts the price

20 OECD Directorate General for Financial and Enterprise Affairs Competition Committee. Algorithms and Collusion - Background Note by the Secretariat DAF/COMP(2017)4, June 9, 2017. 
based on the data obtained from the market. Each of these algorithms persistently and very quickly (using trial and error method) sends to and receives signals from the market as long as it finds the temporary optimum - usually setting the price higher than the real competition would have kept it. It depends a lot on the design of a particular algorithm, whether it is once again "just" an automated implementation of the previously reach understanding about the alignment of prices, or, on the other hand, a perfect follow-up of a market leader, a pure parallelism, without any contact let alone agreements between companies. In the world of brick and mortar shops, an independent adaptation of individual sellers to market changes or to market leader used to be legal and legitimate as without an agreement or exchange of information between undertaking a cartel could hardly happen. ${ }^{21}$ This scenario of a collective elimination of price competition without committing a cartel deserves more attention and will be discussed further.

The latter - fourth - scenario is still a bit of science-fiction from today's perspective. It is the so-called digital eye, or self-learning artificial intelligence, with which the algorithm reaches the level of a transition from a perfect instrument to an autonomously deciding entity. It is expected that such algorithms will self-refine themselves and set their own strategy, not based on some linear sequences of trials and errors, but as a black box that will (like human mind) combine complex sets of data in a way that would be difficult to predict. ${ }^{22} \mathrm{~A}$ preview of this future reality was provided by a PC algorithm called Libratus in early 2017. This creation of researchers from Carnegie-Mellon University in the US was programmed for games based on incomplete information, such as Heads-Up No-Limit Texas Hold'Em poker, however, not equipped with any specific poker game strategy. At the Pennsylvania tournament, Libratus continued to improve for twenty game days, eventually defeating four world's best poker players. These defeated humans later said that Libratus surprised them by the form and variability of his strategy. What human players considered by their experience to be a mistake was usually reversed by Libratus in the winning game. The robot was able to learn from his inhuman mistakes well before his human opponents were able to reveal them and use them against him. ${ }^{23}$

${ }^{21}$ For details see the EU Court of Justice decisions C-199/92 P Hüls AG v. Komise, ECLI:EU:C:1999:358 and C-89/, 104, 114, 116, 125, 125, 129/85 Wood Pulp II. ECLI:EU:C:1993:120.

22 OECD Directorate General for Financial and Enterprise Affairs Competition Committee. It's a Feature, not a Bug: On Learning Algorithms and what they teach us - Note by Avigrdor Gal. DAF/COMOP/WD(2017)50, June 7, 2017, p. 5.

23 OECD Directorate General for Financial and Enterprise Affairs Competition Committee. Algorithmic Collusion: Problems and Counter-Measures - Note by Ezrachi, A. and Stucke, M. E. DAF/COMP/WD(2017)25, May 31, 2017, p. 24. For the report from the tournament see: 
Libratus and his clones are not yet selling on internet markets today, but it cannot be ruled out that they will after 2020 and the competition law will have to cope with the question of who should be held responsible for price collusions that have not been programmed by humans, but the intelligent robots have adopted them on their own without being guided by any person in law.

\section{ANTI-COMPETITIVE ALGORITHMIC PARALLELISM - OFFENSE AND ITS REMEDY}

The third of the above described scenarios of price collusion (predictable agent/ signalling algorithm) is now considered by majority of analysts and institutions to be the real challenge for competition law. This issue is that the classical antitrust, neither in the EU nor in the US, outlaws the unilateral, contactless adaptation to what others are doing. There are no obvious rules that could be enforced in situations when PC algorithms, independently of humans, suppress price competition in a market.

If members of a narrow oligopoly practice a conscious but non-concerted parallelism in pricing, EU competition law could use the institute of collective dominance and could, if prices were inflated, sanction it as an abuse under the Article 102 TFEU. Criteria of a collective dominance ${ }^{24}$, cumulatively required by the Court of Justice in T-342/99 Airtours 2002 decision $^{25}$ and subsequently clarified in C-413/06 P Sony / BMG $2008^{26}$, i.e. the transparent, easily monitored market, the existence of a "retaliation" mechanism detaining attempts to unilaterally divert from a parallel strategy and the absence of an external competitive pressure, seem to correspond to the conditions of pricing through PC algorithms used by 3-4 large companies that benefit from networking effects of the online environment. The abovementioned advantages of the online markets are precisely the transparency of market strategies due to the rapid

Revell, T., AI just won a poker tournament against professional players. New Scientist, January 31, 2017. < https://www.newscientist.com/article/2119815-ai-just-won-a-poker-tournamentagainst-professional-players/ >, last acceessed 12/12/2017.

24 For an overview of the use of the collective dominance concept see: Petit, N., Neyrinck, N. Collective dominance: An overview of national case law. e-Competitions, $\mathrm{N}^{\circ} 39129$. <http:// orbi.ulg.be/bitstream/2268/106843/1/Collective\%20dominance-\%20An\%20overview\%20 of\%20national\%20case.pdf $>$, last accessed 12/12/2017.

25 Case T-342/99 Airtours plc v Commission of the European Communities. Judgment of the Court of First Instance, June 6, 2002. ECLI:EU:T:2002:146.

26 Case C-413/06 P Bertelsmann AG and Sony Corporation of America v Independent Music Publishers and Labels Association (Impala). Judgment of the Court of Justice, July 10, 2008. ECLI:EU:C:2008:392. 
collecting and processing of large volumes of data, the ability to react quickly to changes in competitors' prices (eliminating the desired effect of any price reduction) and therefore also the ability to align prices and maintain them in long term. Contrary to that, it is the inherent dynamism of technology driven markets that could compromise the use of this concept of EU antitrust as rapid innovations, disruptive technologies, shifts in customer preferences etc. make online markets rather unstable, subject to continuous change in market shares and sometimes also in market leaders.

In the United States, antitrust regulations do not sanction such parallel behavior, although one of the classics of the Chicago School of antitrust, R. Posner, proposed already decades ago to interpret the existence of an agreement (that is required for activation of Sec 1 of Sherman Act) so that it would include also a strategy shared contactless by members of an oligopoly. ${ }^{27}$ The US authors are now considering also the use of Sec 5 of the Federal Trade Commission Act that prohibits unfair competition, which may consist in the fact that the company either acquired a certain algorithm with an unfair intention, or at least had to know that the algorithm was designed to avoid price competition. ${ }^{28}$ A bottleneck here is the need to prove the fault of the company, i.e. the causal relationship between the company's intention or negligence and the negative impact of the algorithm on price competition.

But what about the cases that could not be subsumed under the abovementioned provisions of EU and US antitrust and the corresponding competition authorities would appear helpless vis-a-vis the artificially high price level maintained in the long term? There have been four types of approach proposed so far in the running discussion: (i) to refine or extend the interpretation of existing competition rules, (ii) to enact new prohibitions, (iii) to use more intensively some alternative methods of resolving competition cases; (iv) to act in such a way that algorithmic parallelism cannot occur or would be ineffective.

The first approach is based on the premise that these „dangerous“ algorithms had to be created and set in motion by someone, so their design and use in practice can serve as a link between what is happening in the market and the will to collude on the part of the business. It is therefore an extension of the concept of the algorithm being a mere instrument in the hands of an undertaking that, sure did not agree on anything precise with his competitors but set up

27 Mehra, S. K., Antitrust and the Robo-Seller: Competition in the Time of Algorithms. Minnesota Law Review, Vol. 100, 2016 p. 1343.

28 OECD Directorate General for Financial and Enterprise Affairs Competition Committee. It's a Feature, not a Bug: On Learning Algorithms and what they teach us - Note by Avigrdor Gal. DAF/COMOP/WD(2017)50, June 7, 2017, p. 37. 
his PCs to communicate with PCs used by other undertakings, to monitor and follow their prices... and did not equip it with any protection against constant price alignments and increases.

The EU Commissioner for Competition, M. Vestager, seems to prefer just this approach by pushing for "compliance by design". ${ }^{29}$ Under this concept undertakings would be held liable for the software used by their PCs that should have been programmed in a way to be unable to maintain the price strategy shared with competitors. Even at the OECD round table in June 2017 representatives of some EU member states suggested to interpret the term „concerted practice" widely in order to include into it the information exchanges between competitors' PC algorithms, i.e. to treat communications via algorithms as information exchanges evidencing an illegal concerted practice. ${ }^{30}$ Such approach would require from the competition authorities the ability to audit PC algorithms used by companies, which implies the access to the data sets with which the algorithm works and also to the code defining its task. ${ }^{31}$ Without a well-developed practice it is however difficult to tell what are the „bad“ data and tasks assigned to an algorithm and what is the „correct“ brake that should have been built in it.

The second approach proposing big or small legal changes ranges from minor interventions, such as prohibiting automatic price adjustment more than once every 24 hours, to expanding the traditional duo of major antitrust offenses (cartels and abuse of dominant position / monopoly) of a new offense that could be the abuse of excessive market transparency or simply the anti-competitive algorithmic parallelism as a type of behavior different from the permissible "normal" conscious parallelism (market adaptation). ${ }^{32}$ Larger extremes - prohibiting pricing algorithms as such - no one seriously suggests because everybody is aware of their contribution to efficiency and consumer awareness, as well as of the vanity of barring the implementation of new technical gadgets.

\footnotetext{
29 Vestager, M., Algorithms and competition. Bundeskartellamt 18th Conference on Competition, Berlin, 16 March 2017 <https://ec.europa.eu/commission/commissioners/2014-2019/vestager/announcements/bundeskartellamt-18th-conference-competition-berlin-16-march-2017_ en>, last accessed on 12/12/2017.

30 Modrall, J., OECD Workshop Addresses Algorithms and Collusion Issues, Kluwer Competition Law Blog, July 17 2017. < http://competitionlawblog.kluwercompetitionlaw. com/2017/07/17/oecd-workshop-addresses-algorithms-collusion-issues/>, last accessed on $12 / 12 / 2017$

31 OECD Directorate General for Financial and Enterprise Affairs Competition Committee. It's a Feature, not a Bug: On Learning Algorithms and what they teach us - Note by Avigrdor Gal. DAF/COMOP/WD(2017)50, June 7, 2017, p. 6.

32 See for instance: Dylan, I, Ballard, S. N., Algorithms, Artificial Intelligence, and joint Conduct. CPI Antitrust Chronicle, May 2017.
} 
Future legal innovations could also solidify and extend the changes that the abovementioned first approach wants to achieve through interpretation: to enact the strict corporate liability for the algorithms used, or the liability of the person who profits the most of the risk the algorithm has created, or alternatively of the person who could reduce the risk presented by the algorithm (i.e. not only the undertaking - operator of the problematic algorithm but also the undertaking - maker of the algorithm). These options are presented by the European Commission to discussion about the models of responsibility in the context of the digital economy in general. ${ }^{33}$ According to observers, there is currently more firmness on the part of the EU than on the US side ${ }^{34}$, in an attempt to find a way to make companies objectively responsible for their robots even in the absence of any indication of their will to commit a cartel. ${ }^{35}$

A similar strictness appears to be already written into the Australian Competition and Consumer Act of 2010, according to Sec 46 of which, no proof of the "meeting of minds" is required to ensure that companies benefiting from collusion are sanctioned for harm to competition. Commentators say that thanks to this, under Australian law, companies that have benefited from the algorithmic pricing, even from the artificial intelligence mechanisms, they have deployed, can be held responsible, whether or not there was an agreement or the intention to collude. ${ }^{36}$

Intensive use of alternative methods - the third approach of competition authorities - means to talk more often with businesses, to conduct more sectoral investigations, to disseminate exemplary harmless parameters of algorithms tested in public algorithms' incubators, to accept voluntary codes of conduct, to recommend codes of conduct on online markets, etc. The limits of the broadly conceived competition advocacy are wide open, and the myriad of proposals transgress into the fourth group of measures, would rather bet on the prevention of algorithmic parallelism. Here, firstly, it should be possible to limit the emergence of oligopolistic markets. This can be done by stricter merger and takeover assessments in the IT sector, by encouraging start-up

33 Commission Staff Working Document on the free flow of data and emerging issues of the European data economy Accompanying the document Communication Building a European data economy. SWD/2017/02 final, Brussels, 10. 1. 2017.

34 Nylen, L., Newman, M., Views on algorithms and competition law expose EU-US divide. MLex Market Insight, May 26, 2017.

35 Freshfields Bruckhaus Deringer. Pricing Algorithms: the digital collusions scenarios. 2017. < ttps://www.freshfields.com/globalassets/our-thinking/campaigns/digital/mediainternet/pdf/freshfields-digital---pricing-algorithms---the-digital-collusion-scenarios.pdf $>$, last accessed on 12/12/2017.

36 Panichi, J., Seers, P., Newman, M.. Australia reckons it's ready to fight algorithmic collusion as world scramble to review. MLexInsight, November 21, 2017. 
developers of "disruptive" technologies or pro-consumer algorithms that will detect offers not following the existing price collusion etc. There is no doubt that many of these measures that are generally available without the difficult search for a consensus on changes in the laws will see the light very soon. For example, the Korean Competition Authority already uses a PC algorithm to scan the parameters of public tenders and search for bid-rigging indicators, i.e. of the secret alignment of bids in public tenders. ${ }^{37}$

\section{ANTI-COMPETITIVE CONSPIRACY OF ARTIFICIAL INTELLIGENCE}

The above-mentioned case of the Libratus game robot suggests that in the foreseeable future we will also encounter more sophisticated algorithms, which led by the general order "to make profit at the end of the specified period of trading", will develop their own hard-to-analyze strategies. They may include the ability to overcome the restrictions introduced by their law-obeying owners, or even the ,smartness“ to avoid switching-off or blocking - deployed with all the intelligence of the beings struggling to survive. Artificial intelligence experts are already warning that programming such robots in accordance with (effectively interpreted) Asimov's three laws of robotics ${ }^{38}$ will be extremely difficult, if not impossible, because we can translate into the code only unambiguous definitions which, however, we do not have for value-burdened concepts like public good, morality, justice, fairness, general welfare, etc. ${ }^{39}$

The European Parliament is already seriously debating whether to create a separate category of persons in law for advanced artificial intelligence. ${ }^{40}$ This

37 OECD Directorate General for Financial and Enterprise Affairs Competition Committee. Algorithms and Collusion - Background Note by the Secretariat DAF/COMP(2017)4, June 9, 2017, p. 11.

38 Three laws of robotics devised by the world-known sci-fi writer Isaac Asimov: 1) A robot may not injure a human being or, through inaction, allow a human being to come to harm. 2) A robot must obey the orders given it by human beings except where such orders would conflict with the First Law. 3) A robot must protect its own existence as long as such protection does not conflict with the First or Second Laws. See for instance at: < https://www.auburn.edu/ vestmon/robotics.html_>, last accessed on 12/12/2017. These law are referred to also by the European Parliament: Committee of Legal Affairs Draft Report with recommendation to the Commission on Civil Law Rules on Robotics (2015/2013(INL)), p. 4.

39 Umělá inteligence tiká jako bomba (AI is like a ticking bomb), interview of P. Houda with s N. Bostrom in Lidové noviny - Česká pozice 25. 6. 2017. < https://www.pressreader.com/ czech-republic/lidove-noviny/20170624/281513636157560 >, last accessed on 12/12/2017.

40 European Parliament. Committee of Legal Affairs DRAFT REPORT with recommendation to the Commission on Civil Law Rules on Robotics (2015/2013(INL)). 
is only a step away from what was proposed by S. K. Mehra in his widely cited study of $2016^{41}$ : we must decide to hold responsible either the robots themselves or the companies using them (because the alternative of irresponsibility is unacceptable). At this point, a legal and philosophical dispute may open about the existence of freewill in our determined world and whether this useful fiction should be extended to the advanced artificial intelligence. Shortly after, we will have to decide on the type of sanction to be inflicted on robots for their law-breaching behavior. Even if we postpone this debate as largely premature for today, it is already possible to formulate - from the competition law angle - some starting points of future answers.

A smart robot, as proposed by MEPs, will have to be a registered and insured entity. This individualization of robots and also the responsibility that the operator will have vis-a-vis his self-learning robot, make it possible to look for parallels between the responsibility of the company for its employees and for its robots. It is already well established that employers must train and control their employees also in terms of competition protection (well-known antitrust compliance programs). They will have to deal with the robots in the same way as with the employees, because the employers' responsibility for their anti-competitive behavior cannot be but similar. The insertion of competition protecting orders in the robot code will be an attenuating circumstance in the eyes of the competition authority, just like the situation when a "good" robot is seduced to a cartel by a competitor's employee (or robot).

Paradoxically then, the use of current competition law concepts can be made easier by the fiction of the robot's freewill and of its legally significant manifestation than in the case of the present algorithmic parallelism. Nowadays, as outlined above, the algorithm does not have a separate will, while the company may not manifest its own will either, so it is necessary to think about how to re-interpret or change the current competition rules so that an automated result, destructive for competition, can be banned. The analogy between the AI entity and the employee of a company, held equally responsible for both, could make this ban straightforward and undisputable. And until the moment when the laws in force would allow smart robots to run their separate business, or to start a company without the participation of natural or legal persons, this analogy could work well enough. After that moment we will have to have thoroughly thought out whether we would somehow fine the robots, or temporarily disconnect them from the network, or eventually send them to the shredder.

41 Mehra, S. K., Antitrust and the Robo-Seller: Competition in the Time of Algorithms. Minnesota Law Review, Vol. 100, 2016 p. 1323-1375. 


\section{CONCLUSION}

The discussion about influence of PC algorithms on the theory and practice of competition (anti-cartel) law has its practical justification. Already today, in addition to cases where algorithms are used only to better implement a deal or concerted practice agreed between undertakings, possible cases of so-called algorithmic price parallelism occur. They look like a market follow-up strategy or a conscious parallelism through individual adaptation that current competition law does not prohibit either in the EU or in the US, except in the rare cases of a so-called abuse of collective dominant position in EU law. With introduction of modern pricing algorithms, however, the same type of parallel or follow-up behavior can be fatal for price competition in online markets. PC algorithms enable the processing of such a volume of data, plus a very quick and lasting, non-emotional reaction, that the underlying assumptions on which competition protection has so far been built cease to work. Transparency of markets ceases to foster competition, the prisoner dilemma produces a different outcome, and the market can be riddled of price competition without any hint of contact or agreement that is currently considered as prerequisite to a cartel.

The possibility of suppressing price competition in online trading markets cannot but provoke a reaction of the current competition law. We can expect a wide range of measures, of which, apparently, only the last in a row will be the addition of a new type of offense to a classic set of delicts against free and undistorted competition. A more likely solution would be to construe the liability for anticompetitive offense as a strict one as an absolute responsibility for the design or use of an algorithm (of course, together with many sub-measures that will allow to better detect or prevent the algorithmic price parallelism by working upon the parameters and processes of the market as a whole).

Such changes and measures will not yet take the PC algorithm for an independent smart robot, a deep learning artificial intelligence that would choose autonomously (as if of its own will) its market behavior. However, this science-fiction option is already being discussed as a not that distant future to which our society, our markets and our law would enter within one to two decades. In this perspective, it will be necessary to look for parallels first between the robot and the employee and thus consider the responsibility of the employer-undertaking for their acts against competition. In a slightly farther future, the existence of smart robots as independent entrepreneurs or founders and business owners cannot be ruled out - together with their tendency to an anti-competitive behavior that would be evaluated by them as profitable. 


\section{LITERATURE:}

\section{BOOKS}

1. Ezrachi, A., Stucke, M.E., Virtual Competition. The Promise and Perils of the Algorithm-Driven Economy. Harvard University Press 2016.

\section{PAPERS/ARTICLES}

1. Deshayes, M., Les algorithmes, ont-ils pris le pouvoir? Sciences Humaines: Les grandes enjeux du monde contemporain, Mars-Avril 2017.

2. Dylan, I, Ballard, S. N., Algorithms, Artificial Intelligence, and joint Conduct. CPI Antitrust Chronicle, May 2017.

3. Leber, J., The Secrets of Uber's Mysterious Seurge Pricing Algorithm Revelaed, Fast Company Daily Newsletter, October 29, 2015 <https://www.fastcompany.com/3052703/the-secrets-of-ubers-mysterious-surge-pricing-algorithm-revealed $>$.

4. Macaulay, T., Could algorithmic pricing be good for consumers? Techworld, July, $102017<$ http://www.techworld.com/data/could-algorithmic-pricing-make-collusion -invisible-3661103>.

5. Mehra, S., K., Antitrust and the Robo-Seller: Competition in the Time of Algorithms, Minnesota Law Review, Vol. 100, 2016.Mordall, J., OECD Workshop Adresses Algorithms and Collusion Issues: Kluwer Competition Law Blog, July 17, $2017<\mathrm{http} / / /$ competitionlawblog.kluwercompetitionlaw.com/2017/07/17/ oecd-workshop-addresses-algorithms-collusion-issues/>.

6. Nylen, L., Newman, M., Views on algorithms and competition law expose EU-US divide, MLex Market Insight, May 26, 2017.

7. Panichi, J., Seers, P., Newman, M., Australia reckons it's ready to fight algorithmic collusion as world scramble to review, MLexInsight, November 21, 2017.

8. Petit, N., Neyrinck, N., Collective dominance: An overview of national case law. e-Competitions, $\mathrm{N}^{\circ} 39129$ <http://orbi.ulg.be/bitstream/2268/106843/1/Collective\%20dominance-\%20An\%20overview\%20of\%20national\%20case.pdf>.

9. Revell, T., AI just won a poker tournament against professional players, New Scientist, January 31, 2017 <https://www.newscientist.com/article/2119815-ai-justwon-a-poker-tournament-against-professional-players/>.

10. Thomas, A., Algorithmic price-fixing may be the new frontier of antitrust, Fideres.com, March 18, 2016.

11. Vegari, A. N., Lobue, R. P., District Court Finds Uber CEO, by Driving for Uber, May be Liable for Driving Up Prices, Patterson Belknap Antitrust Update, April 6, $2016<$ <ttps://www.antitrustupdateblog.com/district-court-finds-uber-ceodriving-uber-may-liable-driving-prices/>. 
12. Vestager, M., Algorithms and competition, Bundeskartellamt 18th Conference on Competition, Berlin, 16 March 2017 <https://ec.europa.eu/commission/commissioners/2014-2019/vestager/announcements/bundeskartellamt-18th-conference-competition-berlin-16-march-2017_en>.

\section{DOCUMENTS AND REPORTS}

1. Commission Staff Working Document on the free flow of data and emerging issues of the European data economy Accompanying the document Communication Building a European data economy. SWD/2017/02 final, Brussels, 10. 1. 2017.

2. Department of Justice. Press Release Number: 15-421. Former E-Commerce Executive Charged with Price Fixing in the Antitrust Division's First Online Marketplace Prosecution. April 6, 2015. < https://www.justice.gov/opa/pr/former-e-commerce-executive-charged-price-fixing-antitrust-divisions-first-online-marketplace $>$.

3. European Parliament: Committee of Legal Affairs Draft Report with recommendation to the Commission on Civil Law Rules on Robotics (2015/2013(INL)).

4. OECD Directorate General for Financial and Enterprise Affairs Competition Committee. Algorithmic Collusion: Problems and Counter-Measures - Note by Ezrachi, A. and Stucke, M. E. DAF/COMP/WD(2017)25, May 31, 2017.

5. OECD Directorate General for Financial and Enterprise Affairs Competition Committee. It's a Feature, not a Bug: On Learning Algorithms and what they teach us - Note by Avigrdor Gal. DAF/COMOP/WD(2017)50, June 7, 2017.

6. OECD Directorate General for Financial and Enterprise Affairs Competition Committee. Algorithms and Collusion - Background Note by the Secretariat DAF/COMP(2017)4, June 9, 2017.

\section{OTHERS}

1. Freshfields Bruckhaus Deringer. Pricing Algorithms: the digital collusions scenarios, $2017<$ https://www.freshfields.com/globalassets/our-thinking/campaigns/ digital/mediainternet/pdf/freshfields-digital---pricing-algorithms---the-digital-collusion-scenarios.pdf $>$.

2. OECD, Algorithms and Collusion: Competition Policy in the Digital Age,

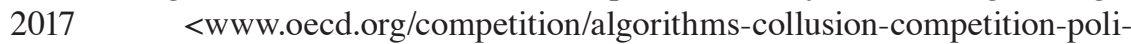
cy-in-the-digital-age.htm>.

3. Umělá inteligence tiká jako bomba (AI is like a ticking bomb), interview of P. Houda with s N. Bostrom, Lidové noviny - Česká pozice 25. 6. $2017<$ https://www. pressreader.com/czech-republic/lidove-noviny/20170624/281513636157560>. 